\title{
Determinants of Share Prices of Listed Companies Operating in the Steel Industry: An Empirical Case from Vietnam
}

\author{
Phu Ha NGUYEN ${ }^{1}$, Phi-Hung NGUYEN ${ }^{2}$, Jung-Fa TSAI ${ }^{3}$, Thanh Tam NGUYEN ${ }^{4}$, \\ Van Nguyen $\mathrm{HO}^{5}$, Trong- Khoi $\mathrm{DAO}^{6}$
}

Received: September 01, 2020 Revised: October 26, 2020 Accepted: November 05, 2020

\begin{abstract}
In accordance with huge demand for capital to meet the expansion of steel production, there are more and more steel companies who have officially listed their stocks in HOSE and HNX. One of the key issues in successful initial public offerings and seasonal offerings for these companies is how to make stocks of steel companies become more attractive in the eyes of investors. The purpose of this research is to analyze the determinants of share prices of listed steel companies in Vietnam. This study utilized macro-economic variables, ratios and indicators representing characteristics of steel industry collected from Quarter 1/2006 to Quarter 4/2019 in association with the panel data and the feasible generalized least square (FGLS) model to evaluate the degree of these factors on the share prices. The results of the research show that ROE, Cons_rate, and CO2_rate are three main factors affecting the share prices of listed steel companies. Among which, ROE and Cons_rate have a positive effect, while CO2_rate has a negative effect on the share prices of listed steel companies. It also confirms the relationship between the environmental factor, construction industry factor and the stock prices. This lays foundations for recommendations for the future policies towards environmental protection and sustainable development.
\end{abstract}

Keywords: Stock Prices, Macroeconomic Variables, CO2 Rate, FGLS, Steel Companies, Vietnam

JEL Classification Code: G15, F31, E44, F37, G01

\section{Introduction}

Since "Doimoi" policy, Vietnamese economy has developed at a relatively high growth rate averaging $6.5 \%$ in the period between 2006 and 2019 (GSO, 2020). Just

${ }^{1}$ First Author. Faculty of Finance \& Banking; College of Economics; Vietnam National University, Hanoi, Vietnam.

Email: haphuvcu@gmail.com

${ }^{2}$ Corresponding Author. PhD Researcher, SAP Lab, Faculty of

Business, FPT University, Hanoi, Vietnam [Postal Address: Hoa Lac

High-Tech Park, Km 29, Thang Long Boulevard, Hanoi, 100000,

Vietnam] Email: hungnp30@fe.edu.vn

${ }^{3}$ Department of Business Management, National Taipei University of

Technology, Taipei, Taiwan. Email: jftsai@ntut.edu.tw

${ }^{4}$ Faculty of Business, FPT University, Hanoi, Vietnam.

Email: tamnt17@fe.edu.vn

${ }^{5}$ Faculty of Business, FPT University, Hanoi, Vietnam.

Email: nguyenhvsb02028@fpt.edu.vn

${ }^{6}$ Faculty of Business, FPT University, Hanoi, Vietnam.

Email: khoidt3@fe.edu.vn

(c) Copyright: The Author(s)

This is an Open Access article distributed under the terms of the Creative Commons Attribution Non-Commercial License (https://creativecommons.org/licenses/by-nc/4.0/) which permits unrestricted non-commercial use, distribution, and reproduction in any medium, provided the original work is properly cited. after 5 years since the officially integrated into the World Trade Organization (WTO) in 2006, Vietnam improved itself to become a middle-income country. Along with industrialization and modernization process, the capital market has also marked 20 years in operation, step by step being upgraded from the frontier market into an emerging market. In addition, the renovation process is followed by a revolution in upgrading transportation networks, roads, industrial zones, new property projects and other infrastructures, leading to high demand on the use of steel. As one of the most important inputs for these concrete structures, the companies and enterprises operating in exploiting irons, manufacturing and importing steel have huge opportunities to expanding their business scale.

From 2000, Vietnam's economy entered a period of opening up and integrating with the world economies, promoting many foreign investment projects. Although the capacity is still maintaining the growth, though if it is compared with other countries in the same region, the level of development of Vietnam is still poor. In the early years of domestic steel production integration, it was not enough to meet the domestic construction demand, some 
industries still had to import raw steel from abroad. After Vietnam joined the WTO (2007), domestic enterprises have made great progress when meeting $100 \%$ of the demand for steel bars, coils, welded steel pipes of all kinds, galvanized steel, and color coating. Currently, before the unpredictable developments of the COVID-19 epidemic, the steel industry is like the Vietnamese economy that is significantly affected. Although Vietnam is in a period of good disease control, the growth of the industry is showing signs of being threatened due to low demand for people and limited supply when the epidemic in the world does not show to be getting under control and there are signs that it will flare up again.

The steel industry is one of the key industries of the economy. The steel industry therefore has very strict industry standards, including the international ISO standard. From a business analysis perspective, the steel industry is considered a highly complex industry. Businesses in the steel industry often encounter major issues such as: defining the basic components of the production process (plate, volume, volume, grade of steel), costing, coordination between business and production, planning and production schedules, control progress, product traceability. In addition, with high technical characteristics, the amount of input information of the production system is very large. In order to maintain the efficiency of stable production and supply chains, steel companies need a comprehensive enterprise management solution that is strong and flexible enough to meet current regulations as well as new regulations and market fluctuations.

Manufacturing steel is complicated by many models, processes, equipment and many impacting factors. In order to make the production process to work, it is necessary to perform a lot of calculations and increase the scope of the questionnaire in order to find the optimal solution. Randomness: Large fluctuations, uncertain conditions, may change the production schedule in the middle, and there may be problems during the production process (equipment failure, need repair, change delivery date) goods, baked steel does not meet standards ...).

Raw ores need to be processed before they can be made to produce steel, the waiting time of each furnace must be shorter than the time required by the crude production process. To increase the output, the molding machines need to work continuously. Moreover, some equipment need regular maintenance, such as those in the kiln area. They are the rules that are required at the time of production planning. Many objects: The rate of finished products and production time need to be improved. Those are important goals to consider in managing steel production. In addition, making use of efficient resources, reducing costs, meeting customers' required delivery deadlines, and much more needs to be managed as objects in the metal manufacturing process. Different goals also have different influences on how to handle specific problems. During the steel production process of enterprises, the conveyor of raw materials should be operated in the most efficient manner. Lines need to be closely linked, production lines should also be considered in order to realize the balance between resources including task division on the various steel furnaces, lathes, and machines castings, rolling machines and furnaces.

According to statistical data provided by POSRI, GSO and CTS, the use of steel in areas of civil construction, infrastructure, construction in manufacturing industries, shipping lines and others accounts for 33\%, 17\%, 15\%, $15 \%$ and $20 \%$ in period 2015-2019. Besides, VSA (2020) also reported that the fast development of Vietnamese steel industry with the average speed of 7.7 percent annually creates more pressure for domestic companies in mobilizing sufficient sources of funds for expanding the business scale. In addition, the banks and other financial intermediaries recently mentioned side effects of steel production in their report on green banking, raising social concerns about the air pollution and future development of the industry.

Obviously, the future development of Vietnamese steel industry is associated with 3 key strategies, i.e., investing in green technologies, strengthening sources of funds by equity issues and increasing market valuation. By 2020, there are 300 companies and enterprises working in steel industry, but there are only 19 of them officially listed in Ho Chi Minh Stock Exchange (HOSE) and Hanoi Stock Exchange (HNX). Most of these listed companies in the steel industry improved their business performance, and 15 of them ranked in the list of the best 100 companies in Vietnamese stock market during 2006-2019 (VSA, 2020).

This context also addresses 2 assumptions. First, listed steel companies in Vietnamese stock exchange are under pressure to increase their size of equity, so as to meet requirements for restructuring the industry towards eco-friendly development. Second, investors in the markets have interest in the share prices of steel industry. Whether or not the macro-economic factors and environmental factors of steel manufacturing and other variables have impacted the behavior of stock prices of steel industry lay foundations for governmental strategies for long-term development of this industry. Therefore, we focus on the following issues: (i) Determinants of stock prices of publicly traded companies in the steel industry. (ii) The relationship of their stock prices with Pollution Control and Construction Development in Vietnam.

It is designed into 5 sections. Section 2 focuses on literature review highlighting empirical studies methodologies used in previous studies about determinants of stock prices. Section 3 highlights the variables, hypotheses and data processing. Section 4 conducts data analysis and summarizes key findings. Finally, the authors sum up conclusions and recommendations to investors, managers and authorities to develop strategies based on factors influencing behavior of share prices of steel companies. 


\section{Literature Review}

Both theories and many empirical researches suggest that macroeconomic factors can affect the stock market, including money supply, interest rates, exchange rates, GDP, inflation, and gold prices. Within the limits of this study, the author chooses the experimental results of the impact of some macroeconomic factors on stock prices, namely: Inflation, interest rates and GDP. The increase in inflation is usually a sign that the growth of the economy will be unsustainable, interest rates will increase, and the profitability of businesses will be lowered, causing stock prices to decline. The lower the inflation, the more likely the stocks will rise and vice versa. Although there is still much controversy about the value of GDP, it is still the basic indicator for assessing the growth of the economy. Stock prices tend to increase when the economy develops and decrease when the economy slows down. This is reasonable because when the economy develops then there is more availability of capital to be invested.

Professional investors are very concerned with a company's governance and business results because of their effect on the stock price. If a company has high revenue, high profit after tax, stable growth and regular dividends for its shareholders, then the stock price will surely increase because investors will have the trust to invest in the company with the desire to make a lot of profits. In contrast, if the business results have plummeted, the stock price will decrease because the business will not be able to win the trust of the investors in this situation. Therefore, the indicators showing the business results of the company such as ROE, ROA, and Dividend yield expressed through financial statements will have impacts on the stock prices. In addition, other indicators reflecting the company's governance such as debt ratio, quick ratio, inventory turnover will also affect stock prices. Because these indicators represent the quality of management and the strategies of the company's management. A well-managed company that has an effective business strategy as well as using capital effectively will attract more investors, and its share price will increase due to the increase in investors' buying demand.

Market factors, which are internal market factors, include market volatility and the relationship between supply and demand, can be considered the third group of factors affecting stock prices. The market volatility is a phenomenon of overstatement from overestimating the true value of a stock when its price is high due to the company's prosperity, and vice versa due to a low prediction of value at the time the market goes down. The relationship between supply and demand is directly reflected in the volume of transactions in the market, the transactions of institutional investors, margin trading, etc., also have a significant effect. Some of the market indices include P/E, EPS, and VN index.
During the last 2 decades, a great deal of literature emphasized on evidence and testing either the causal links or the effects of socio-economic, monetary policies and internal business factors of listed companies associated with the behaviour of financial assets' prices. Specifically, (Makinde, 2015) investigated the relationship of dividend, money supply, interest rate, foreign exchange and inflation rate and share price movements in Naira Stock Exchange for the year from 1991 to 2013 by employing the multiple regression model. They found that dividend, money supply and interest rate serve as strong determinants of the share price.

Later, Bhargava et al.,(2016) examined the relationship between macro-economic variables, monetary indicators and the real commodities' prices, which include inflation, the index of industrial production (IIP), money supply, oil prices, exchange rates, gold prices, gross domestic product (GDP) and the stock prices in India for the period 2004-2013 using time series regression. According to these authors, oil prices, exchange rate provide good explanations for changes in stock prices. In which, exchange rate, and the inflation rate are negatively related to stock prices, but the oil prices are positively related. Moreover, gold prices, money supply, IIP, and GDP have an insignificant impact over the stock prices.

In the research about key factors affecting the stock price of enterprises listed in HOSE, Nguyen et al., (2019) used data from 100 largest companies in terms of market capitalization in between 2015 and 2018 using the linear regression analysis. The findings of the study indicated that five factors i.e., EPS, USD/VND exchange rate, interest rate, gold price, and CPI definitely affect the stock prices with a significance level of $1.0 \%$. Besides, the USD/VND exchange rate, EPS, and interest rate had a positive impact on the stock price. In contrast, gold price and CPI had a negative relationship with the movement of the stock prices.

Recently, Nguyen et al., (2020) evaluated the stock prices of agriculture companies indexed on the Vietnam Stock Exchange Market during the 2016-2019 periods. The AHP method is used to determine the importance of the proposed financial ratios. The findings suggest that the integrated model could be implemented effectively to specific analysis of industries such as oil, steel, gas, and textiles in future research.

Qaisi et al.,(2016) investigated the influence of financial indicators and companies' characteristics on the stock prices of twenty insurance companies listed in Amman stock exchange during the period 2011 and 2015. With application of multiple linear regression, they found evidences about the statistical significance between ROA, debt ratio, the age, size of the company, and market stock price in which, ROA was positively related to the stock price. Sharif et al.,(2015) investigated the impact of eight specific variables namely ROE, P/B, EPS, DPS, dividend yield, P/E, debt to assets, and firm size on the market share prices of 41 companies listed 
in the Bahrain Stock Exchange for the period 2006-2010. This study used pooled OLS regression with robust standard errors, fixed effects and random effects models. The results indicated that the explanatory variables including return on equity, book value per share, dividend per share, dividend yield, price earnings ratio, and firm size are significant determinants of share prices in the Bahrain market. Their findings showed a positive relationship between $\mathrm{ROE}, \mathrm{P} / \mathrm{B}$, DPS, P/EE, firm size and market share price. In contrast, there is a significant negative relationship between dividend yield and market share price. Moreover, debt ratio and EPS have an insignificant relationship with the market share price.

Besides empirical studies on the impact of economic and business environment indicators on the behaviour of stock prices in different markets at different time span, studies focusing on determinants of share prices of companies operating in steel industry are few. A survey study of Allahawiah and Amro (2012) aimed at identifying the impact of both internal and external factors in the market share price of listed companies in the Amman Stock Exchange (ASE) from the respondent's opinions, which include descriptive and analytical methods. There are 60 out of 227 listed companies in ASE selected by a random sampling. The empirical findings showed that six factors i.e., dividend policy, management quality, financial position, liquidity saving, asset size, and the nature of firm work have a positive relationship with the market stock prices. Moreover,

Lee \& Brahmasrene (2018) investigated dynamic relationships between selected macroeconomic variables and stock prices in the Korea Stock Exchange. The data is restricted to the period for which monthly data was available from January 1986 to October 2016 (370 observations) and was retrieved from the Economic Statistics System database sponsored by the Bank of Korea. The study employs unit root test, cointegration test, vector error correction estimates, impulse response test, and structural break test. The results of the Johansen cointegration test indicate at least three cointegrating equations exist at the 0.05 level in the model, confirming that there is a long-run equilibrium relationship between stock prices and macroeconomic variables in Korea. In Vietnam, Dang et al.,(2020) analyzed factors affecting enterprise's financial risk listed on the Vietnam stock market for a period of eleven years, from 2009 to 2019.

Moreover, Khan (2012) clarified the effect of dividend announcements on stock prices of the twenty-nine Pakistan companies listed at KSE-100 Index in the chemical and pharmaceutical industry from the period of 2001 to 2010. Their results showed that Stock Dividend, Earnings per Share and Profit after Tax have a significant positive relation to stock market prices and significantly explicates the variations in the stock prices of chemical and pharmaceutical sector of Pakistan while Retention Ratio and Return on Equity have the negative insignificant relation with stock prices.
In this research, financial risk is measured by the Alexander Bathory model. Debt structure, Solvency, Profitability, Operational ability, Capital structure are independent variables in the study. Firm Size, firm age, growth rate are control variables. The findings of this article are useful for business administrators, helping business managers make the right financial decisions to improve the efficiency of financial risk management in enterprises.

\section{Methodology}

This study uses secondary data collected from database of General Statistics Office of Vietnam, Fiin Group, and other sources from official websites of HOSE, HNX, and database of the World Bank. Collection period is from the first quarter of the year 2006 to the fourth quarter of the year 2019. As each listed company has a different listing time, the panel data in this study is the unbalanced panel data. The authors only selected data of 10 out of 19 companies as only this much data was available, This made the total number of 484 observations by the end of the year 2019. The model is suggested as the following:

$$
\begin{aligned}
\text { Price }_{i t} & =\beta_{0}+\beta_{1} \text { Debt }_{i t}+\beta_{2} \text { ROE }_{i t}+\beta_{3} P / E_{i t}+\beta_{4} C P I_{i t} \\
& +\beta_{5} \text { GDP }{ }_{i t}+\beta_{6} \text { Cons_rate }_{i t}+\beta_{7} \text { Pop_rate }_{i t} \\
& +\beta_{8} \text { CO2_rate }{ }_{i t}+\varepsilon_{i t}
\end{aligned}
$$

The dependent variable used in the model is the stock price of listed companies classified into the steel industry. The stock price applied in this research is the adjusted price corresponding to the closing price at the last trading day of each quarter, and it is collected from Quarter 1/2006 to Quarter 4/2019. The symbol is $\mathrm{Y}_{\mathrm{i}, \mathrm{t}}$ denoted as company $i$ with $i=1,2, \ldots, 10$ and year $t$ with $t=1,2 \ldots . .56$.

Based on literature review synthesized in section 2, $G D P$ and $C P I$ are selected to present for macro-economic and monetary indicators, while $R O E$, debt rate and $P / E$ are ratios representing financial indicators of the company $i$. Specifically, with the purpose to fill the literature gap, our research team proposed three new variables, which include Pop_rate, CO2_rate, and Cons_rate In fact, iron exploitation and production of steel in Vietnam caused a lot of pollution, $\mathrm{CO} 2$ rate can represent for the pollution indicator. In the meantime, the urbanization and development of property projects as well as concrete infrastructure require the consumption of steel, Cons_rate can represent the development of construction industry, which indirectly reflects the consumption of steel. Besides, Pop_rate also indirectly reflect the demand for accommodation and urbanization, leading to the consumption of steel. The detail description on the set of variables and formula have been summed up in the table 1. 
Table 1: Summary of Variable Description

\begin{tabular}{|c|c|c|c|}
\hline Variables & $\begin{array}{c}\text { Descriptive } \\
\text { Data collected by the end of the quarter }\end{array}$ & Unit & Formular \\
\hline Share price & $\begin{array}{l}\text { The closing price on the last trading day of } \\
\text { the year }\end{array}$ & VND & The adjusted price applied for closing price \\
\hline Debt & Debt ratio of 10 selected companies & $\%$ & Total debt/Total assets \\
\hline ROE & ROE of 10 selected companies & $\%$ & $\begin{array}{l}\text { Profit after tax for shareholders of the parent } \\
\text { company/Total equity }\end{array}$ \\
\hline$P / E$ & $\mathrm{P} / \mathrm{E}$ of 10 selected companies & Multiple & The closing price/Earnings per share \\
\hline CPI_rate & Consumer price index of Vietnam & $\%$ & $\begin{array}{l}\left(\mathrm{CPI} \text { rate quarter }-\mathrm{CPI} \text { rate quarter } t_{t-1}\right) / \\
\text { CPI_rate quarter }\end{array}$ \\
\hline GDP_rate & $\begin{array}{l}\text { Gross domestic product growth rate of } \\
\text { Vietnam }\end{array}$ & $\%$ & $\begin{array}{l}\left(\text { GDP_rate quarter-GDP_rate quarter } r_{t-1}\right) / \\
\text { GDP_rate quarter }_{t-1}\end{array}$ \\
\hline Pop_rate & Population growth rate of Vietnam & $\%$ & 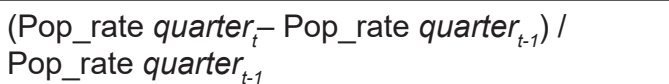 \\
\hline Cons_rate & $\begin{array}{l}\text { Construction industry growth rate of } \\
\text { Vietnam }\end{array}$ & $\%$ & $\begin{array}{l}\text { (Accounting value of the construction industry } \\
\left.\text { in quarter } r_{t} \text { - that of quarter }{ }_{t-1}\right) / \text { accounting value } \\
\text { of the industry in quarter } t_{t-1}\end{array}$ \\
\hline CO2_rate & $\mathrm{CO} 2$ emissions growth rate of Vietnam & $\%$ & $\begin{array}{l}\left(\mathrm{CO} 2 \text { rate quarter } r_{t}-\mathrm{CO} 2 \text { _rate quarter } t_{t-1}\right) / \\
\mathrm{CO} 2 \text { rate quarter } t_{t-1}\end{array}$ \\
\hline
\end{tabular}

Firstly, the stepwise method is applied to select the most suitable independent variables for the model (Hocking, 2009). Results from Dicky Fuller Test and the descriptive statistics shows that the share price is stationed at the first difference and the collected data is satisfied conditions for the multiple linear regression (Table 2). After the completion of running regression applied to cases of the Pool OLS, FEM, and REM, the result of Hausman test is used to check the suitability between REM and FEM. The Sigma_more option in Hausman test is selected as it provides more accurate estimation of covariance matrices in the multivariate regression model than the normal Hausman test (Greene, 2000). Then, if the Hausman test shows that REM is a more suitable model, the Breusch Pagan Lagrangian Multiplier test is used to determine the suitability between REM and Pooled OLS. Otherwise, the F-test is used to select whether or not FEM is more suitable than Pooled OLS. Finally, multicollinearity, heteroscedasticity, and autocorrelation are also checked if they exist in the model.

\section{Results and Discussion}

Among eight explanatory variables suggested, we applied the stepwise method to determine the most suitable variables for the model based on the $t$-value. The retained variables in the model is understood as the one whose betacoefficient associated with the highest absolute $t$-value.
Table 2: Descriptive Statistics

\begin{tabular}{|l|c|c|c|c|c|}
\hline Variable & Obs & Mean & Std.Dev. & Min & Max \\
\hline Price & 484 & 19423 & 16530 & 3700 & 95000 \\
\hline ROE & 484 & 10.688 & 15.68 & -49.12 & 51,35 \\
\hline Cons_rate & 484 & 7.342 & 3.84 & -0.23 & 12.01 \\
\hline CPI_rate & 484 & 7.133 & 5.69 & 0.67 & 19.9 \\
\hline CO2_rate & 484 & 8.29 & 6.505 & -0.85 & 19.38 \\
\hline Pop_rate & 484 & 1.019 & 0.03 & 0.92 & 1.06 \\
\hline
\end{tabular}

This is a forward selection process in which once a variable is selected, it cannot be removed from the model, and the process is repeated until no more explanatory variable is statistically significant with the dependent variable. Based on the stepwise method, the five independent variables are selected, which include ROE, Cons_rate, CPI_rate, CO2_rate, and Pop_rate. Result of Hausman test shows that the $p$-value is equal to 0.0801 , which is higher than 0.05 , so the Ho hypothesis is not rejected, and REM model is considered to be more effective. Then, Breusch Pagan Lagrangian Multiplier test is used to determine between REM and Pooled OLS, showing the p-value equivalent to 0.0021 , which is lower than 0.05 . Therefore, the Ho hypothesis is rejected and REM model is selected in this test. Finally, both results from the Hausman test and Breusch Pagan Lagrangian. 
Table 3: Collin Test Results

\begin{tabular}{|l|c|c|c|c|}
\hline Variable & VIF & SQRT VIF & Tolerance & R-Squared \\
\hline Price & 1.88 & 1.37 & 0.5340 & 0.4660 \\
\hline ROE & 1.48 & 1.17 & 0.7246 & 0.2754 \\
\hline Cons_rate & 4.64 & 2.15 & 0.2171 & 0.7829 \\
\hline CPI_rate & 4.01 & 2.03 & 0.2432 & 0.7568 \\
\hline CO2_rate & 1.63 & 1.28 & 0.6089 & 0.3911 \\
\hline Pop_rate & 2.34 & 1.54 & 0.4202 & 0.5798 \\
\hline Mean VIF & 2.65 & & & \\
\hline
\end{tabular}

Table 4: FGLS Results

\begin{tabular}{|l|c|c|c|c|c|c|}
\hline D.Price & Coef. & Std.Err. & $\mathbf{z}$ & $\mathbf{P}>|\mathbf{z}|$ & \multicolumn{2}{|c|}{ [95\% Conf. Interval] } \\
\hline ROE D1. & 249.66 & 62.52 & 3.99 & 0.000 & 127.11 & 372.21 \\
\hline Cons_rate D1. & 2193.92 & 454.86 & 4.82 & 0.000 & 1302.40 & 3085.43 \\
\hline CPI_rate & 239.52 & 521.49 & 0.46 & 0.646 & -782.58 & 1261.63 \\
\hline CO2_rate D1. & -452.75 & 163.77 & -2.76 & 0.006 & -773.73 & -131.77 \\
\hline Pop_rate D1. & -110066.2 & 131665.6 & -0.84 & 0.403 & -368126.1 & 147993.7 \\
\hline cons & -3196.6 & 3446.77 & -0.93 & 0.354 & -9952.14 & 3558.94 \\
\hline
\end{tabular}

Multiplier test confirmed about the suitability of REM model as the best one to use for regression analysis. Results from Collin test in Table 3 showed that mean VIF value is equal to 2.65, which is smaller than 5. It meant that there is no multi-collinearity existing in the REM model.

From Wooldridge test, the p-value resulted equals 0.2983, which is higher than 0.05 and Ho hypothesis is accepted, meaning that there is no autocorrelation in the model (Wooldridge, 2010). According to Breusch and Pagan (1979), Breusch Pagan Lagrangian Multiplier test is not only used to determine between REM and Pooled OLS model but also served for purpose to identify if heteroscedasticity exists in the model. In terms of assumptions about heteroskedasticity being violated, the feasible generalized least squares method (FGLS) is considered to be an appropriate choice (Hoechle, 2007).

The result after using FGLS model in Table 4 shows that the current model is homoskedastic. In addition, the research results show that the share prices of listed steel companies are affected by $\mathrm{ROE}$, Cons_rate, and $\mathrm{CO} 2$ rate. Cons_rate has the largest impact factor among three variables, while $R O E$ and the share price show the positive correlation. Results in table 3.5 also confirms results and conclusions from previous studies of Sharif, et al., (2015) at the Bahrain stock exchange.

However, conclusion of this study is contradicted to the study of Qaisi et al.,(2016) at Amman stock exchange. Specifically, if Cons_rate, CO2_rate, CPI_rate, and Pop_ rate are kept constant, then $\mathrm{ROE}$ increase by $1 \%$ causes the price increase by 249.66 VND per share respectively. This relationship is statistically significant at $1 \%$. Similar to $R O E$, the results also indicate that the Cons rate is positively correlated with the share price at a statistically significant level of $1 \%$. Cons rate is one of three new variables introduced in this study to fill the current research gap, and we confirmed that it is the most important explanatory variable. If $\mathrm{ROE}, \mathrm{CO} 2$ rate, $C P I$ rate, and Pop_rate remain unchanged, then Cons_rate increases $1 \%$ causes the share price to increase by $2193.92 \mathrm{VND}$. In contrast to $R O E$ and Cons rate, the $C O 2$ rate has a negative relationship with the stock price, having statistical significance at $1 \%$. If $R O E$, Cons_rate, CPI_rate, and Pop rate are kept constant, then the $\overline{C O} 2$ rate increased by $1 \%$ will lead to the fall of the share price by 452.75 VND. Though both CPI_rate and Pop_rate show links with the share prices, none of them statistically significant. 


\section{Conclusions and Recommendations}

The paper provided empirical evidence of the relationship between $R O E$ and the share price, reflecting the direct response of share prices to the business performance of the steel companies in the long run. The movements of ROE can be the signal for the future price of the stocks. If the business performance is improved in the long run, the stock becomes more attractive to the investors. Interestingly, the share prices of steel companies in Vietnamese security market is strongly affected by the development of construction industry. The author used the Cons_rate as a representative for the growth rate of the construction. It is believed that the more development of the construction industry, the more opportunity for the stock price of steel companies to increase in the market if the demand increases. Furthermore, the CO2-rate strongly and negatively affect fluctuations of the share prices, proving that the increase in $\mathrm{CO} 2$ emissions give a lot of pressure to increase investment expenditure for technologies and solutions to pollution related environmental problems. It can be understood that old technologies, natural resources exploitation and pollution are the negative aspects associated with steel production. This is also the factor which can cause a fall in the share prices of the steel companies in the future.

In addition, this study provides empirical evidences for anyone who is concerned about investment in stocks of steel industry. Firstly, it can serve as a reference for potential investors who are pursuing long-term strategy investment. Those who have been considering to hold the stocks of steel companies should evaluate carefully the business performance associated with profitability, and technologies used to produce steel and protect the environment. Secondly, share prices of the steel companies have parallel movements with the ups and downs of the construction industry. The more they pay attention to the stock of the steel industry, the more they should make analysis on related policies governing the overall construction projects, industrial zones and infrastructures development. Third, this paper also proposes recommendations to the listed steel companies. Improvements in share prices are advantages for them to issue more stocks and mobilize more cash flows for business expansion. The steel companies should make strategic planning on shifting the current technology into advanced technology, so as to reduce the $\mathrm{CO} 2$ emissions. In terms of financing side, the banks and credit providers should apply credit scoring based more on criteria on environment protection and eco-friendly technology in production of steel and construction. Finally, the paper also proposes recommendations to the government, the
State Security Committee of Vietnam on their future policies towards strengthening rules and regulations on environmental disclosure.

\section{References}

Allahawiah, S., \& Amro, S. Al. (2012). Factors affecting Stock Market Prices in Amman Stock Exchange: A Survey Study. European Journal of Business and Management, 4(8), 236-246. Retrieved from http://iiste.org/Journals/index.php/ EJBM/article/view/1951

Bhargava, A., Bhargava, A., \& Jain, S. (2016). Factors Affecting Stock Prices in India: A Time Series Analysis. IOSR Journal of Economics and Finance, 7(4), 68-71. https://doi. org/10.9790/5933-0704016871

Breusch, T. S., \& Pagan, A. R. (1979). A Simple Test for Heteroscedasticity and Random Coefficient Variation. Econometrica, 47, 1287. https://doi.org/10.2307/1911963

Dang, H. T., Phan, D. T., Nguyen, H. T., \& Hoang, L. H. T. (2020). Factors Affecting Financial Risk: Evidence from Listed Enterprises in Vietnam. Journal of Asian Finance, Economics and Business, 7(9), 11-18. https://doi.org/10.13106/jafeb.2020. vol7.no9.011

Greene, W. H. (2000). Econometric Analysis (4 ${ }^{\text {th }}$ ed.). Upper Saddle River, NJ: Prentice-Hall.

Hocking, A. R. R. (2009). A Biometrics Invited Paper . The Analysis and Selection of Variables in Linear Regression Published by: International Biometric Society Stable URL : http://www.jstor. org/stable/2529336. Society, 32(1), 1-49.

Hoechle, D. (2007). Robust standard errors for panel regressions with cross-sectional dependence. Stata Journal, 7(3), 281-312. https://doi.org/10.1177/1536867x0700700301

Hung, N. K., Tuan, G. Q., Phuong, D. T. M., Thang, L. D., \& Hien, N. A. (2019). Key factors affecting the stock price of enterprises listed on ho chi minh stock exchange. Academy of Accounting and Financial Studies Journal, 23(6), 2635.

Khan, K. I. (2012). Effect of dividends on stock prices-A case of chemical and pharmaceutical industry of Pakistan. Management, 2(5), 141-148.

Lee, J. W., \& Brahmasrene, T. (2018). An exploration of dynamical relationships between macroeconomic variables and stock prices in Korea. Journal of Asian Finance, Economics and Business, 5(3), 7-17. https://doi.org/10.13106/jafeb.2018.vol5. no3.7

Makinde, H. O. (2015). Determinants of Share Price Movement in Nigeria: The Management Perspective. International Journal of Business, Economics and Management, 2(10), 209-221. https://doi.org/10.18488/journal.62/2015.2.10/62.10.209.221

Nguyen, P. H., Tsai, J. F., Kumar G, V. A., \& Hu, Y. C. (2020). Stock Investment of Agriculture Companies in the Vietnam Stock Exchange Market: An AHP Integrated with GRA-TOPSISMOORA Approaches. Journal of Asian Finance, Economics, 
and Business, 7(7), 113-121. https://doi.org/10.13106/jafeb. 2020.vol7.no7.113

Qaisi, F. Al, Al-qudah, M., \& Tahtamouni, D. A. (2016). Factors Affecting the Market Stock Price: The Case of the Insurance Companies Listed in Amman Stock Exchange. International Journal of Business and Social Science, 7(10), 81-90. https:// doi.org/ISSN: 2219-1933
Sharif, T., Purohit, H., \& Pillai, R. (2015). Analysis of Factors Affecting Share Prices: The Case of Bahrain Stock Exchange. International Journal of Economics and Finance, 7(3). https:// doi.org/10.5539/ijef.v7n3p207

Wooldridge, J. M. (2010). Econometric analysis of cross section and panel data. Cambridge, MA: MIT Press. 